\title{
Study of the effect of diatomite on physico-mechanical properties of concrete
}

\author{
(Estudo do efeito da diatomita nas propriedades \\ físico-mecânicas do concreto)
}

\author{
A. R. S. Macedo' ${ }^{1 *}$, A. S. Silva ${ }^{1}$, D. S. da Luz L. R. L. S. Ferreira $^{1}$, C. S. Lourenço ${ }^{1}$, U. U. Gomes ${ }^{2}$ \\ ${ }^{1}$ Universidade Federal do Rio Grade do Norte, Programa de Pós-Graduação em Ciência e Eng. dos Materiais, \\ R. das Engenharias, s/n, 59078-9004, Natal, RN, Brazil \\ ${ }^{2}$ Universidade Federal do Rio Grande do Norte, Programa de Pós-Graduação em Eng. Civil, Natal, RN, Brazil
}

\begin{abstract}
Concretes present great potential to be used in many areas of civil construction. Their properties can be improved by substitution or addition of alternative materials to the Portland cement. The diatomite is a sedimentary material composed mainly by silica and amorphous impurities, presenting very fine particle size, high porosity, and low specific mass. Concrete was produced in a ratio of 1:1:2 (cement: sand: gravel) with the addition of diatomite at contents of $5 \%$ and $10 \%$ by cement weight and a water/cement ratio of 0.54 . The physico-mechanical properties of the concretes were evaluated by tests of compressive strength and water absorption by immersion. Also, X-ray diffraction and scanning electron microscopy were carried out to analyze the main phases in the cement paste. The results indicated that the addition of diatomite in the concrete increased the compressive strength due to the silica content in the material and reduced slightly the porosity.
\end{abstract}

Keywords: concrete, diatomite, physico-mechanical properties.

\section{Resumo}

Os concretos apresentam alto potencial de uso nas mais diversas áreas da construção civil e suas propriedades podem ser melhoradas através da utilização de materiais alternativos por substituição ou adição ao cimento Portland. A diatomita é um material sedimentar composto principalmente por sílica e impurezas amorfas e possui granulometria muito fina, alta porosidade e baixa massa especifica. Foram produzidos concretos em proporção de 1:1:2 (cimento: areia: brita) com adição de diatomita em niveis de 5\% e 10\% em massa de cimento e relação água/cimento de 0,54. As propriedades físico-mecânicas dos concretos foram avaliadas por meio dos ensaios de resistência à compressão e absorção de água por imersão. Também foram realizados ensaios de difratometria de raios X e microscopia eletrônica de varredura para análises das principais fases na pasta de cimento. Os resultados indicaram que a adição de diatomita no concreto aumentou a resistência à compressão devido ao teor de sílica no material e reduziu levemente a porosidade.

Palavras-chave: concreto, diatomita, propriedades físico-mecânicas.

\section{INTRODUCTION}

Nowadays, due to rapid economic development and population growth, there is a strong demand for the use of natural resources available in most parts of the world, especially in Brazil. These resources have been studied and applied increasingly in the production of various materials, such as concrete. The incorporation of natural resources into concrete leads to environmental, economic and technological benefits, since one of the most important constituents of concrete is cement, which presents high costs and causes environmental damages due to its production. In this way, the use of natural resources that present pozzolanic properties has gained great importance in the civil construction

*amandamacedoengcivil@gmail.com

Dhttps://orcid.org/0000-0002-2910-9697 industry [1]. In modern cement and concrete technology, the addition of active mineral additives, such as fly ash, active silica, slag, and pozzolan, is of great scientific significance. One of these materials that have a high natural content of amorphous active silica is diatomite, mostly composed of silica and small amounts of residual minerals. The diatomite is a biogenic sedimentary rock with a high content of natural amorphous silica [2]. Most of the amorphous silica is in the form of diatomaceous frustules and, secondarily, in the form of sponge spicules and silicone flagellate skeletons. This type of $\mathrm{SiO}_{2}$ can react with $\mathrm{Ca}(\mathrm{OH})_{2}$ and produce calcium silicate hydrate (CSH). Thus, as a result, there is an increase in the quality and quantity of the hydrates, and the compressive strength of the cement paste and other properties can be greatly improved $[3,4]$.

In general, diatomite is considered a natural lightweight aggregate with high surface area and pozzolanic activity. For 
these reasons, it can be used in the concrete manufacture, either as a partial replacement or as an addition to Portland cement [2,3]. Its production consists of three distinct stages: mining, beneficiation, and calcination. The diatomite deposits are formed by dry and submerged terraces (in ponds, estuaries, closed bays), existing open pit mining, dredging, and tunnels. Tilling is done with the removal of organic matter and vegetation present on the mine surface. Then, the diatomite is pumped and deposited in a tank with water for the formation of a pulp, being taken into settling tanks where the separation of the clay occurs. The calcination of the diatomite is carried out with the addition of a flux which has the auxiliary function in the particle agglomeration and scoring of the impurities. This mixture is sent to the calcination furnace, between 1000 and $1200{ }^{\circ} \mathrm{C}$, according to the organic matter content in the diatomite. After being calcined, the diatomite is cooled and disaggregated. The products obtained are subjected to specific tests according to their application purpose [5].

Concrete properties, particularly compressive strength, depend strongly on its microstructure, which is influenced by several parameters, such as type, quantity, and structure of its constituent materials. The constituent materials of the concrete include fine and coarse aggregates and the hydrated cement paste as a binder resulting from the hydration or pozzolanic reaction of cementitious materials. The structure of the concrete is greatly influenced by the hydration reaction speed, reaction products, and their distribution in the paste of hydrated cement. In addition, the rate of hydration reactions and products can be substantially modified by the use of chemical and mineral additives [6]. In the microstructure of the concrete, it is possible to find the hydrated phases of the cement paste, as well as solid crystals of calcium hydroxide, thin and long needles of ettringite, and aggregates of small fibrous crystals of hydrated calcium silicates. When the cement is dispersed in water, the calcium sulfate and the calcium compounds formed at high temperatures begin to solubilize and the liquid phase rapidly becomes saturated with several species of ions. As a result of the interaction between calcium, sulfate, aluminate and hydroxyl ions, within a few minutes of cement hydration, acicular crystals of hydrated calcium trisulfoaluminate, known as ettringite, begin to appear. A few hours later, large prismatic calcium hydroxide crystals and small fibrous crystals of hydrated calcium silicates begin to fill the voids previously occupied by water and dissolved cement particles. After a few days, depending on the alumina-sulfate ratio of the Portland cement, the ettringite may become unstable and decompose to form the hydrated monosulfoaluminate, with the shape of a hexagonal plate [7].

The study of the diatomite as mineral addition in cements and concrete is still incipient in the literature, mainly because of some studies show that its incorporation does not improve the mechanical properties, due to lower pozzolanic reactivity and its greater porosity $[1,8,9]$, resulting in a greater demand for water to maintain the workability. In a recent study [9], it was observed that concretes with diatomite show high porosity due to two factors. The first factor is the increased water content, promoted by the high porosity of diatomite particles, which implies a concrete mortar also very porous; and the second factor is related to the lower pozzolanic reactivity of the diatomite. It was concluded that the use of a water reducing agent can contribute to the elimination of most cement clusters, making the system more reactive and accelerating the hydration reactions, increasing the available calcium hydroxide for the reaction continuously [9]. However, other authors [10] studied the use of calcined diatomaceous aggregate in light concrete properties. The results indicated that the incorporation of diatomite increased the strength and reduced the density and thermal conductivity of concretes compared to those with untreated diatomite. Finally, the use of calcined diatomite at high temperatures, like $500{ }^{\circ} \mathrm{C}$, is necessary to improve the concrete properties. Another study [3] suggested that the replacement of cement by diatomite (5\% to 10\%) increased the mechanical strength of the concrete due to reactive silica and the high surface area of this material. This research studied the effects of the addition of 5 and $10 \mathrm{wt} \%$ of diatomite in concrete on physico-mechanical and microstructural properties of Portland cement concretes. Thus, this study aimed to contribute to the formation of a database on the subject, in order to encourage the use of diatomite in building materials and, consequently, promote sustainable development of civil construction.

\section{MATERIALS AND METHODS}

Raw materials and characterization: Portland cement of high initial resistance, with a specific gravity of $3.14 \mathrm{~g} / \mathrm{cm}^{3}$ [11] and compressive strength of $27.36 \mathrm{MPa}$ and $45.22 \mathrm{MPa}$ at 3 and 28 days, respectively, was used. This cement was characterized by its high initial strength, and also by high reactivity at low ages due to the grinding which was subjected, with the peculiarity of reaching high resistance in the first days of application. As a fine aggregate, natural river sand was used, and granitic gravel was used as coarse aggregate. They are widely used in civil construction in the region of Rio Grande do Norte State (Northeast, Brazil). The diatomite used was acquired from the municipality of Rio do Fogo in Barra de Punaú, State of Rio Grande do Norte, showing a cream color after calcination at $1000^{\circ} \mathrm{C}$. This temperature was consistent with a previous study [10], which indicates that the ideal calcination temperature for the reactive diatomite should not be less than $500{ }^{\circ} \mathrm{C}$. The diatomite used as an additive in the concretes was initially calcined at $1000{ }^{\circ} \mathrm{C}$. The result of the thermogravimetric analysis of the diatomite is presented in Fig. 1a. The material presented significant mass loss until $1000{ }^{\circ} \mathrm{C}$, presenting a greater mass loss between 100 and $400{ }^{\circ} \mathrm{C}$. The diatomite's particle size distribution was evaluated with a laser diffraction granulometer (Cilas, 920L). Water was used as a circulating fluid and no dispersing agent was used. The granulometric range adopted was $0.10-500 \mu \mathrm{m} / 100$ classes and ultrasound was applied for $60 \mathrm{~s}$. Fig. $1 \mathrm{~b}$ shows the particle size distribution curve of the 
diatomite powder. The distribution curve showed the values for $\mathrm{D}_{10}, \mathrm{D}_{50}$ and $\mathrm{D}_{90}$ of, respectively, 0.63, 3.83 and 21.58 $\mu \mathrm{m}$, and an average particle size of $8.35 \mu \mathrm{m}$.
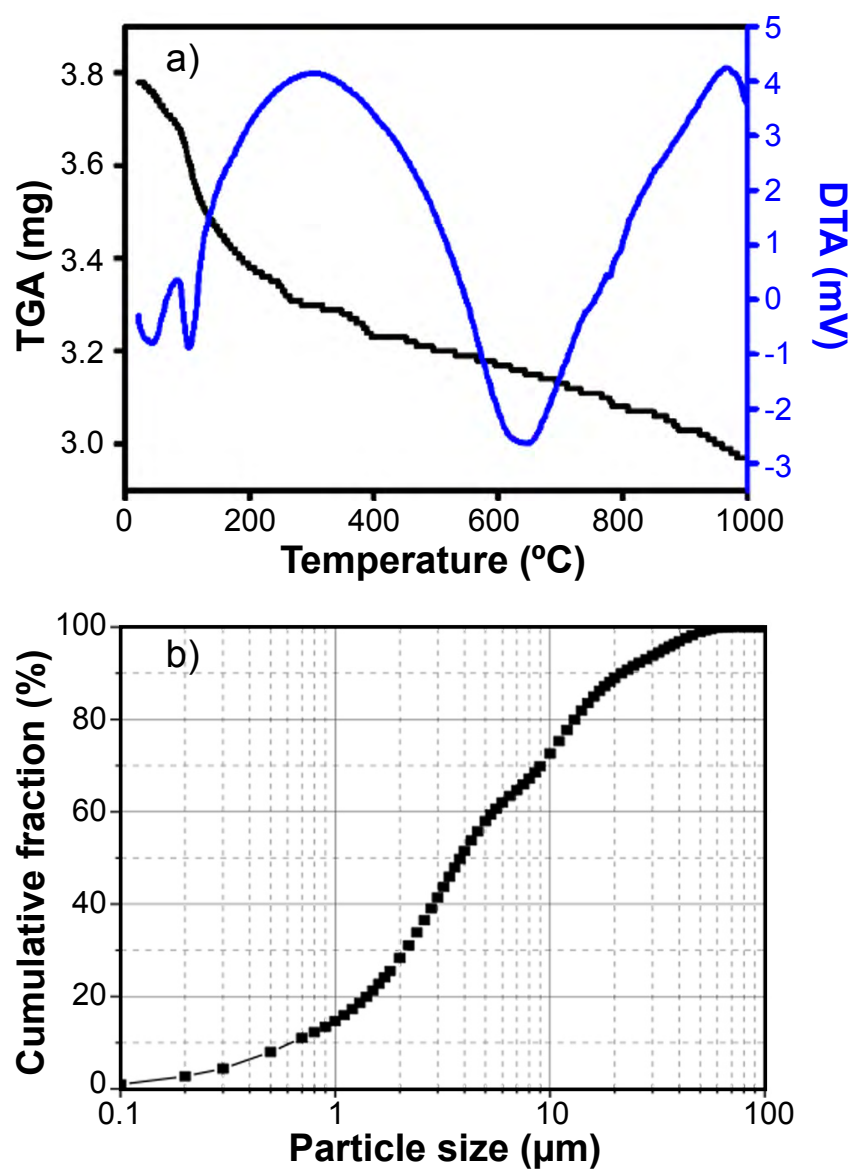

Figure 1: Thermogravimetric (TGA) and differential thermal analysis (DTA) curves (a) and particle size distribution curve (b) of diatomite powder.

[Figura 1: Curvas de termogravimetria, TGA, e análise térmica diferencial, DTA (a), e curva de distribuição de tamanho de partícula (b) do pó de diatomita.]

Table I shows the chemical composition of diatomite, determined by X-ray fluorescence (XRF) spectroscopy (Shimadzu, EDX-720); the method applied was semiquantitative, under vacuum. The results indicated a predominance of silica $(70.77 \%)$, zirconia $(11.28 \%)$ and iron oxide $(9.02 \%)$. Chemically, the diatomite had a composition rich in silica and poor of impurities. For the mineralogical analysis, the technique of X-ray diffraction (XRD, Shimadzu, XRD-6000) was used. The sample was subjected to the following analysis conditions: $K \alpha$ radiation of a copper anode $(1.54056 \AA)$, voltage of $30 \mathrm{kV}$ and current of $30 \mathrm{~mA}$, with a $2 \theta$ angle ranging from $5-80^{\circ}$ with an angular velocity of $5 \% \mathrm{~min}$ and step of $0.02^{\circ}$. Fig. 2a presents the X-ray diffractogram of the diatomite powder, showing crystalline peaks related to quartz and cristobalite. The morphology of the diatomite was observed by scanning electron microscopy (SEM, Hitachi, TM-3000). A SEM micrograph can be observed in Fig. 2b. It is important to highlight that the morphology was navicular type, a characteristic of this material. The studied diatomite consisted of cylindrical shaped particles with a square cell structure and a surface composed of micropores, justifying the high porosity and low density of this material, as it was observed in previous studies $[8,10,12,13]$. Table II shows the results of maximum particle size, fineness modulus, specific gravity and bulk density of the aggregates: sand and gravel. These results were in accordance with the specifications required by the Brazilian standard NBR 7211 [14] - aggregates for concrete fabrication.
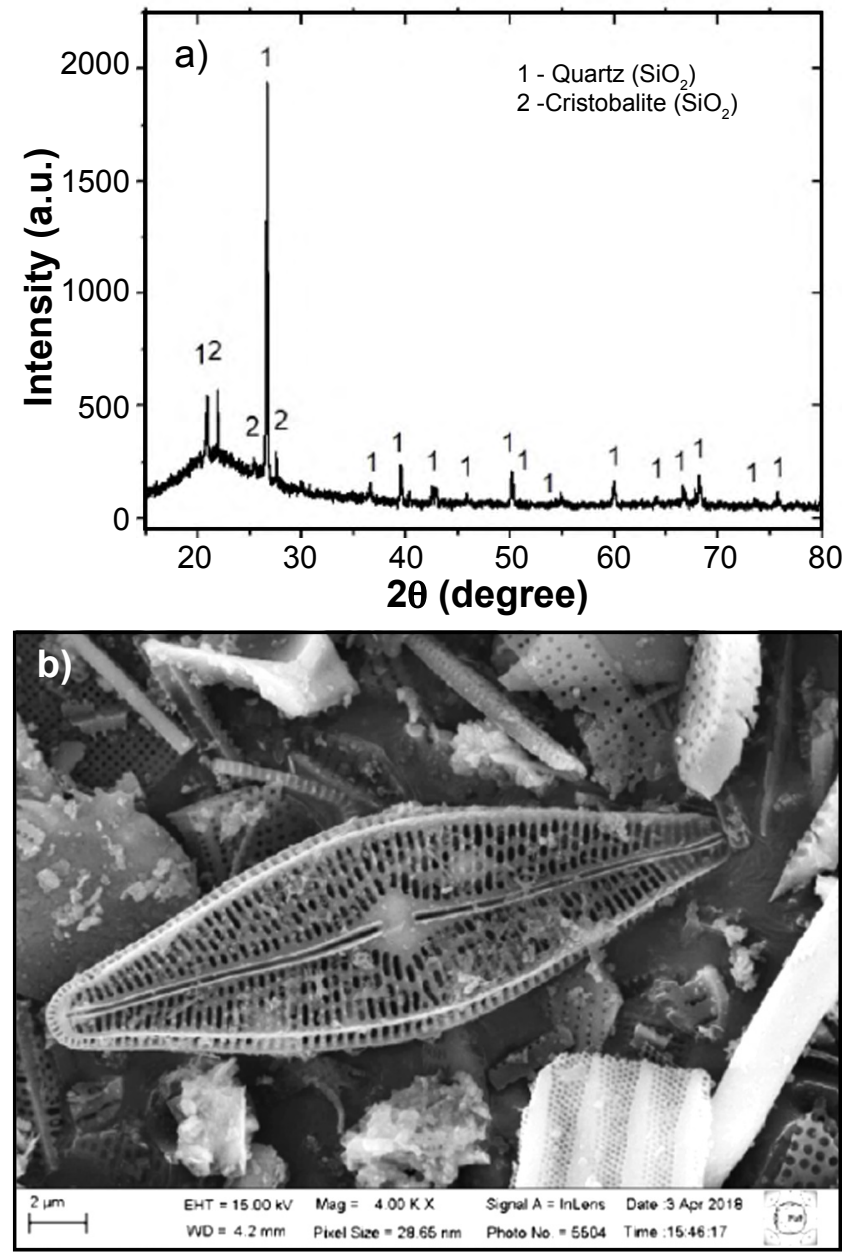

Figure 2: X-ray diffractogram (a) and SEM image (b) of diatomite powder.

[Figura 2: Difratograma de raios $X(a)$ e imagem de $M E V(b)$ do pó de diatomita.]

Table I - Chemical composition of diatomite powder (wt $\%$ ).

[Tabela I - Composição química do pó de diatomita (\% em massa).]

\begin{tabular}{cccccccccc}
\hline $\mathrm{SiO}_{2}$ & $\mathrm{ZrO}_{2}$ & $\mathrm{Fe}_{2} \mathrm{O}_{3}$ & $\mathrm{Al}_{2} \mathrm{O}_{3}$ & $\mathrm{CaO}$ & $\mathrm{K}_{2} \mathrm{O}$ & $\mathrm{MnO}$ & $\mathrm{SrO}$ & $\mathrm{Cr}_{2} \mathrm{O}_{3}$ & $\mathrm{~S}$ \\
\hline 70.77 & 11.28 & 9.02 & 6.61 & 1.14 & 0.51 & 0.22 & 0.22 & 0.15 & 0.08 \\
\hline
\end{tabular}


Table II - Physical characteristics of the aggregates. [Tabela II - Características físicas dos agregados utilizados.]

\begin{tabular}{ccc}
\hline Characteristic & Sand & Gravel \\
\hline Maximum size $^{\mathrm{a}}(\mathrm{mm})$ & 2.4 & 9.5 \\
Fineness modulus $^{\mathrm{a}}$ & 2.72 & 5.34 \\
Specific gravity $^{\mathrm{b}}\left(\mathrm{kg} / \mathrm{dm}^{3}\right)$ & 2.59 & 2.63 \\
Bulk density $^{\mathrm{c}}\left(\mathrm{kg} / \mathrm{dm}^{3}\right)$ & 1.39 & 1.32 \\
\hline Standard: $^{a} N B R N M 2^{248[15] \cdot{ }^{b} N B R N M} 52[16] . N M 53[17] \cdot{ }^{c} N B R$ &
\end{tabular}

Modified Chapelle's method: the method used to determine the pozzolanic activity index of diatomite was applied to measure the content of calcium hydroxide, accordingly to the method prescribed in NBR 15895 [19]. The method consisted in the capacity of the diatomite to fix the calcium hydroxide, by pozzolanic action, for the formation of hydrated compounds. It consisted of a mixture of $1.0 \mathrm{~g}$ of diatomite and $2.0 \mathrm{~g}$ of calcium hydroxide in 250 $\mathrm{mL}$ of $\mathrm{CO}_{2}$-free water, packed in a polymeric Erlenmeyer flask, held for a period of $16 \pm 2 \mathrm{~h}$ at $90 \pm 5^{\circ} \mathrm{C}$. The result, obtained by titration, was expressed by the amount of calcium hydroxide per gram of diatomite.

Production and characterization of concrete: the quantities of the materials were determined considering the desired strength of the concrete. For the strength of $35 \mathrm{MPa}$, the mixture proportion used was 1:1:2 (cement: sand: gravel). The diatomite was used as an additive in proportions of $5 \%$ and $10 \%(\mathrm{w} / \mathrm{w})$, according to the cement mass. The water/cement $(\mathrm{w} / \mathrm{c})$ ratio used was 0.54 . The quantities of materials used to manufacture the test specimens are shown in Table III. The mixtures for the concrete production were mechanically mixed, with the aid of a concrete mixer with a capacity of $400 \mathrm{~L}$. It should be highlighted that the aggregates were washed and dried in a laboratory oven prior to the use. The concretes with the addition of diatomite showed reduced slump test values and consequent reduction of the workability, when compared to the reference concrete. In order to minimize these effects, a correction in the water/cement $(\mathrm{w} / \mathrm{c})$ ratio was performed; no superplasticizer was used in this study. The w/c ratio adopted before and after the correction was, respectively, 0.45 and 0.54 . The correction was performed by adding $50 \mathrm{~mL}$ of water to the mixture, keeping constant the amounts of the other constituents. After mixing, 3 specimens (for each test and proportion of mixture) were molded with cylindrical metallic molds, $10 \mathrm{~cm}$ in diameter by $20 \mathrm{~cm}$ in height, according to NBR 5738 [21]. After 24 $\mathrm{h}$, the specimens were demolded and cured by immersion in water saturated with calcium hydroxide for 28 days for further analysis of compressive strength (NBR 5739 [22]) and water absorption index (NBR 9778 [23]). After the rupture, samples were collected in order to determine the hydration of the cement, as well as the effects of diatomite addition in the microstructure. The analyzed samples were reduced to a size below $75 \mu \mathrm{m}$ using a porcelain mortar and 200-mesh sieve. Then, they were analyzed by XRD and SEM, whose parameters and equipment were described before. For microstructural analysis by SEM, samples obtained from the test specimens after 28 days of cure were used.

\section{RESULTS AND DISCUSSION}

The modified Chapelle method was used to indicate the pozzolanic activity of the diatomite through the consumption of calcium hydroxide, presenting a consumption of $650 \mathrm{mg} \mathrm{Ca}(\mathrm{OH})_{2} / \mathrm{g}$ added. The values of lime consumption were above $330 \mathrm{mg} \mathrm{CaO} / \mathrm{g}$ of addition, equivalent to $436 \mathrm{mg} \mathrm{Ca}(\mathrm{OH})_{2} / \mathrm{g}$ of addition, whose value is the minimum established in [24] for classification of the mineral addition as pozzolanic material. In this way, it was possible to state that the use of diatomite as a mineral additive had reactivity, being considered pozzolan. The $\mathrm{X}$-ray diffractograms in Fig. 3 shows the phases resulting from the hydration of the cement for the respective concrete studied. The phases of calcium silicate hydrate (CSH), portlandite $(\mathrm{CH})$, gismondine (CASH), and ettringite were observed in both concretes with the addition of diatomite, however, some of them presented lower peak intensities. The presence of the CSH and CASH phases favored the increase of strength for these concretes when compared to the reference concrete, which was directly related to the pozzolanic activity of the diatomite shown by the Chapelle method. The chemical reaction between amorphous silica $\left(\mathrm{SiO}_{2}\right)$ in diatomite and portlandite and/or other hydrated products in the cement matrix, in alkaline media, resulted in the formation of CSH and CASH [3, 25].

Fig. 4 presents SEM micrographs of the concretes without and with diatomite addition of 5 and $10 \mathrm{wt} \%$ showing

Table III - Mass of materials used for the preparation of concrete specimens and results of slump test and water/cement (w/c) ratio of the mixture.

[Tabela III - Massa dos materiais utilizados para confecção dos corpos de prova de concreto e resultados do ensaio de abatimento e relação água/cimento $(w / c)$ da mistura.]

\begin{tabular}{cccccccc}
\hline Mixture & Cement $(\mathrm{g})$ & Sand $(\mathrm{g})$ & Gravel $(\mathrm{g})$ & Water $(\mathrm{g})$ & Diatomite $(\mathrm{g})$ & Slump test* $(\mathrm{cm})$ & w/c \\
\hline $0 \%(\mathrm{ref})$ & 537 & 537 & 1074 & 295 & 0 & 7 & 0.54 \\
$5 \%$ & 537 & 537 & 1074 & 295 & 26.85 & 5 & 0.54 \\
$10 \%$ & 537 & 537 & 1074 & 295 & 53.7 & 4 & 0.54 \\
\hline
\end{tabular}

* NBR NM 67 standard [20]. 


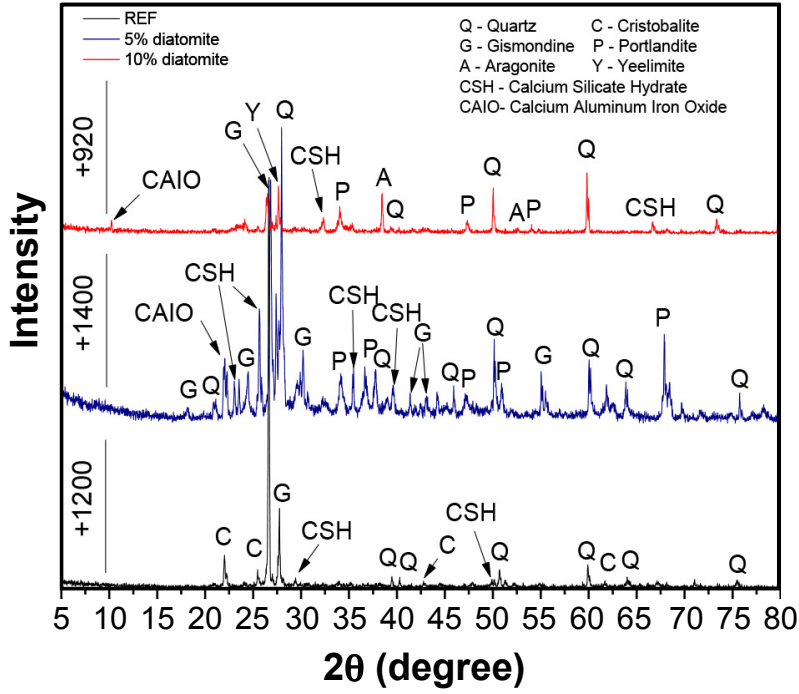

Figure 3: X-ray diffractograms of the concretes without (REF) and with addition of 5 and $10 \mathrm{wt} \%$ of diatomite.

[Figura 3: Difratogramas de raios $X$ dos concretos sem $(R E F) e$ com adição de $5 \%$ e $10 \%$ de diatomita.]

the morphologies of the phases in the cement matrix, as well as the homogeneity and compactness of the concrete microstructure. It was possible to observe the characteristic morphologies of: $\mathrm{CSH}$ as nanometric particles aggregated to each other; ettringite as acicular crystals; and gismondine stacks that were similar to a crown. The high fineness of the diatomite powder caused the obstruction of pores, with a microfiller effect of the voids and, consequently, resulting in a compact and homogeneous microstructure, as can be seen in Figs. $4 \mathrm{~b}$ and $4 \mathrm{c}$.

Fig. 5 a shows the results of the water absorption index and porosity for concretes without and with diatomite addition of 5 and $10 \mathrm{wt} \%$. It was observed that the addition of diatomite in the mixtures reduced the porosity and the water absorption index of the concrete, even though the diatomite had a rather porous morphology. This was associated with the effect of micro-filled voids, as mentioned previously, reducing the porosity of the concretes and consequently resulting in lower water absorption. The hydration of the cement and pozzolanic reactions occurred within the capillary pores and were, therefore, responsible for the matrix densification [9] and reduction of porosity due to the diatomite incorporation.
The results were also in accordance with previous studies $[3,10]$ and indicated that the diatomite with a high surface area filled the voids and reduced the porosity of the concrete.

In Fig. 5b, it is possible to observe a significant increase in the values of compressive strength with the addition of
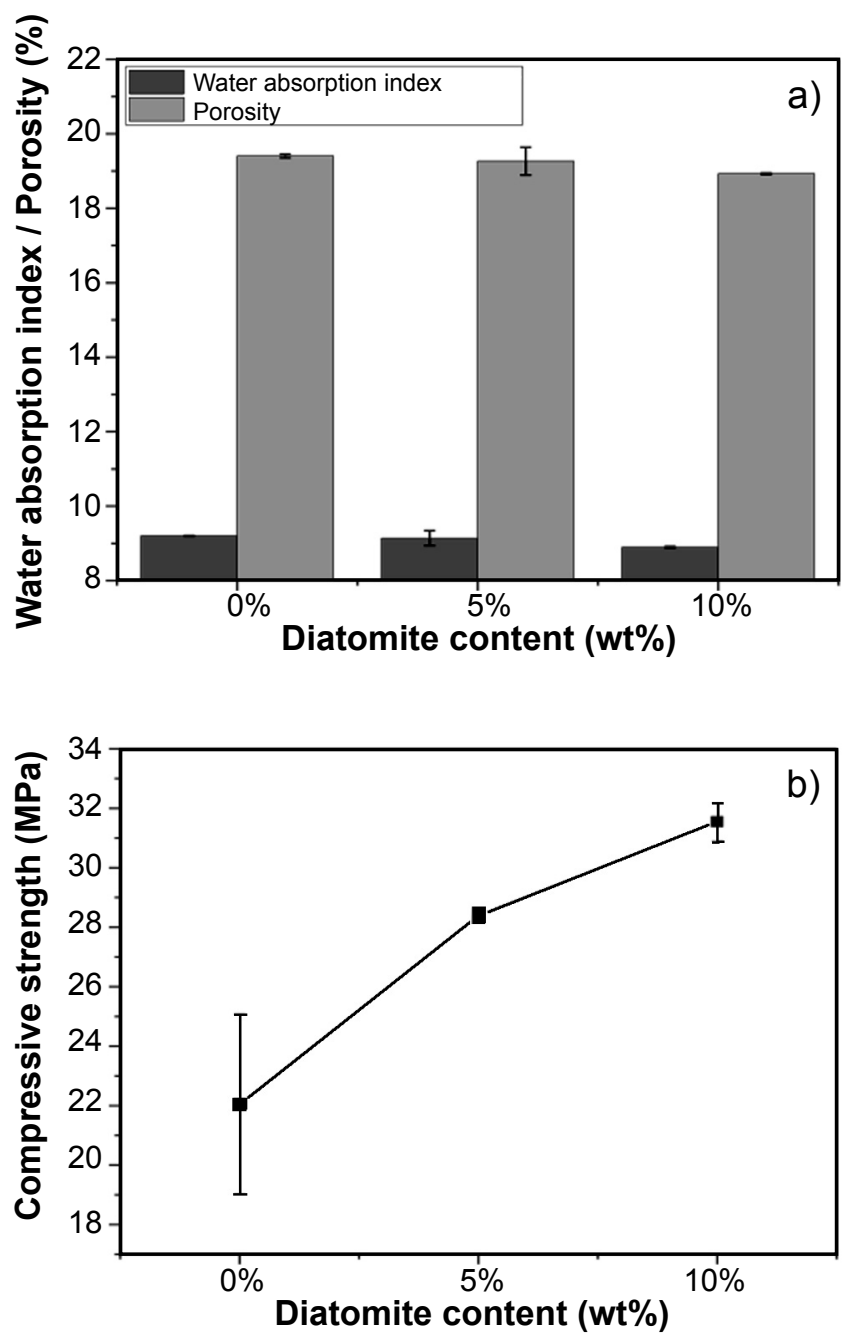

Figure 5: Results of water absorption index and porosity (a) and compressive strength (b) of concretes with diatomite addition of 0,5 and $10 \mathrm{wt} \%$.

[Figura 5: Resultados de índice de absorção de água e porosidade (a) e resistência à compressão (b) dos concretos com adição de 0 , $5 \%$ e $10 \%$ de diatomita.]
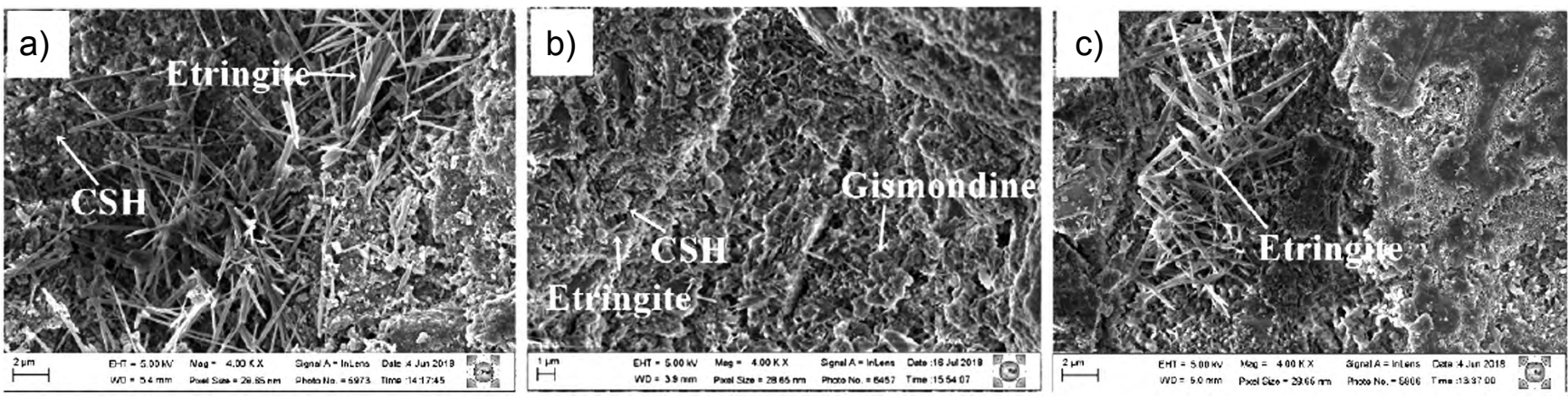

Figure 4: SEM images of the concretes with diatomite content of: a) $0 \%$; b) $5 \mathrm{wt} \%$; and c) $10 \mathrm{wt} \%$.

[Figura 4: Imagens de MEV dos concretos com teor de diatomita de: a) 0\%; b) 5\%; e c) $10 \%$ (\% em massa).] 
diatomite when compared to the reference concrete $(0 \%$ of diatomite). The best result was obtained for the concrete with $10 \mathrm{wt} \%$ of diatomite. These results confirmed those obtained by XRD and SEM of the studied concrete, i.e., the formation of hydrated products and consequently the densification of the structure favored the increase of concrete strength by the addition of diatomite, in accordance with a previous study [3], where the pozzolanic reaction between the amorphous silica of the diatomite and the calcium hydroxide of the hydration reactions produced the $\mathrm{CSH}$, making the concrete produced with diatomite more homogeneous, dense and strong. Diatomite had a large surface area and pozzolanic property, which caused the increase of the strength values of the studied concretes (Fig. 5). The main factors that affected the contribution of diatomite in strength were: filler effect, due to the high surface area of the diatomite that filled the voids; better linkage between matrix and diatomite [10]; and the pozzolanic reaction of diatomite's silica with $\mathrm{CH}$, which produced the hydrated calcium silicates which were responsible for the increase in compressive strength. It is important to highlight that the compressive strength improvement was not only associated with the CSH formation, since the formation of gismondine was partially responsible for the paste compaction and, consequently, the increase in the strength. Thus, the concrete strength depended on the combination of the clinker hydration and the pozzolanic activity of the diatomite $[3,25]$.

\section{CONCLUSIONS}

The addition of diatomite in concrete production was investigated in this study. The following conclusions can be drawn: i) the diatomite studied was considered pozzolanic, presenting a pozzolanic activity index of $650 \mathrm{mg}$ of $\mathrm{Ca}(\mathrm{OH})_{2} / \mathrm{g}$ of diatomite, in which the active silica reacted with the calcium hydroxide present in the cement, forming hydrated silicates and gismondine, increasing the concrete compressive strength; ii) the addition of the diatomite in the concrete, despite having a porous microstructure, did not change significantly the porosity and water absorption index of the concretes; and iii) the diatomite studied improved the physical and mechanical properties of the concrete. Better results were obtained for the concrete formulated with a diatomite addition of $10 \mathrm{wt} \%$.

\section{ACKNOWLEDGMENTS}

The authors would like to acknowledge the National Council for Scientific and Technological Development (CNPq), Coordination for the Improvement of Higher Education Personnel (CAPES), and PPGCEM-UFRN for the support granted to this study.

\section{REFERENCES}

[1] A.C. Aydin, R. Gül, Constr. Build. Mater. 21 (2007) 1277. [2] V. Letelier, E. Tarela, P. Muñoz, G. Moriconi, Constr. Build. Mater. 114 (2016) 492.

[3] A. Ergün, Constr. Build. Mater. 25 (2011) 806.

[4] X. Pu, Cem. Concr. Res. 29 (1999) 951.

[5] P.L.B. da Silva, L.D.A. de Sousa, V.P. da Silva, E. Harima, J.Y.P. Leite, Holos 3 (2010) 52.

[6] R. Demirboğa, I. Örüng, R. Gül, Cem. Concr. Res. 31 (2001) 1627.

[7] P.K. Mehta, P.J.M. Monteiro, Concrete: microstructure, properties, and materials, Pini, S. Paulo (2006) 684.

[8] B. Yilmaz, N. Ediz, Cem. Concr. Compos. 30 (2008) 202.

[9] H. Paiva, A.S. Silva, A. Velosa, P. Cachim, V.M. Ferreira, Constr. Build. Mater. 140 (2017) 374.

[10] P. Posi, S. Lertnimoolchai, V. Sata, P. Chindaprasirt, Constr. Build. Mater. 47 (2013) 896.

[11] NBR 16605, "Cimento Portland e outros materiais em pó determinação da massa específica", ABNT, Rio Janeiro (2017).

[12] K. Pimraksa, P. Chindaprasirt, Ceram. Int. 35 (2009) 471.

[13] K. Pimraksa, P. Chindaprasirt, A. Rungchet, K. SagoeCrentsil, T. Sato, Mater. Sci. Eng. A 528 (2011) 6616.

[14] NBR 7211, "Agregados para concreto - especificação", ABNT, Rio Janeiro (2009).

[15] NBR NM 248, “Agregados - determinação da composição granulométrica”, ABNT, Rio Janeiro (2003).

[16] NBR NM 52, "Agregado miúdo - determinação da massa específica e massa específica aparente", ABNT, Rio Janeiro (2009).

[17] NBR NM 53, "Agregado graúdo - determinação de massa específica, massa específica aparente e absorção de água", ABNT, Rio Janeiro (2003).

[18] NBR NM 45, "Agregados - determinação da massa unitária e do volume de vazios", ABNT, Rio Janeiro (2006).

[19] NBR 15895, "Materiais pozolânicos - determinação do teor de hidróxido de cálcio fixado - método Chapelle modificado", ABNT, Rio Janeiro (2010).

[20] NBR NM 67, "Concreto - determinação da consistência pelo abatimento do tronco de cone", ABNT, Rio Janeiro (1998).

[21] NBR 5738, "Concreto - procedimento para moldagem e cura de corpos de prova", ABNT, Rio Janeiro (2015).

[22] NBR 5739, "Concreto - ensaio de compressão de corpos de prova cilíndricos", ABNT, Rio Janeiro (2018).

[23] NBR 9778, "Argamassa e concreto endurecidos determinação da absorção de água, índice de vazios e massa específica", ABNT, Rio Janeiro (2009).

[24] R. Raverdy, M. Brivot, F. Paillere, A.M. Dron, in $7^{\text {th }}$ Int. Congr. Chem. Cem., Paris (1980).

[25] S.W. Tang, X.H. Cai, Z. He, H.Y. Shao, Z.J. Li, E. Chen, Constr. Build. Mater. 113 (2016) 939.

(Rec. 31/08/2018, Rev. 02/04/2019, 05/07/2019, Ac. 20/08/2019) 